\title{
Phylogenetic diversity of dominant bacterial communities during bioremediation of crude oil-polluted soil
} (http://dx.doi.org/10.4136/ambi-agua.186)

\author{
Chioma B. Chikere* $^{1}$; Karen J. Surridge ${ }^{2}$; Thomas E. Cloete ${ }^{3}$; Gideon C. Okpokwasili ${ }^{1}$ \\ ${ }^{* 1}$ Department of Microbiology, University of Port-Harcourt, Nigeria. \\ e-mail: *1'Corresponding author: ujuazed@yahoo.com; ${ }^{1}$ gidsilman@yahoo.com \\ ${ }^{2}$ Department of Plant Production and Soil Science, University of Pretoria, Republic of South Africa. \\ e-mail: karen.surridge@up.ac.za \\ ${ }^{3}$ Department of Microbiology, Stellenbosch University, Republic of South Africa. \\ e-mail: eugenecloete@sun.ac.za
}

\begin{abstract}
Bioremediation of hydrocarbon pollutants is advantageous owing to the costeffectiveness of the technology and the ubiquity of hydrocarbon degrading microorganisms in the soil. Soil microbial diversity is affected by hydrocarbon perturbation thus selective enrichment of hydrocarbon utilizers occurs. Hydrocarbons interact with the soil matrix and soil microorganisms determining the fate of the contaminants relative to their chemical nature and microbial degradative capabilities respectively. Bacterial dynamics in crude oil-polluted soil microcosms undergoing bioremediation were investigated over a 42-day period. Four out of the five microcosms containing $4 \mathrm{~kg}$ of pristine soil each were contaminated with $4 \%$ Arabian light crude oil. Three microcosms were amended with either 25g of NPK fertilizer, calcium ammonium nitrate or poultry droppings respectively while the fourth designated oilcontaminated control was unamended. The fifth microcosm had only pristine soil and was set up to ascertain indigenous bacterial community structure pre-contamination. Biostimulated soils were periodically tilled and watered. Hydrocarbon degradation was measured throughout the experimental period by gas chromatography. Gas chromatographic tracing of residual hydrocarbons in biostimulated soils showed marked attenuation of contaminants starting from the second (day 14) till the sixth (day 42) week after contamination whereas no significant reduction in hydrocarbon peaks was seen in the oil contaminated control soil throughout the 6-week experimental period. Molecular fingerprints of bacterial communities involved in aerobic biodegradation of crude oil hydrocarbons in biostimulated soils and controls were generated with DGGE using PCR-amplification of 16S rRNA gene obtained from extracted total soil community DNA. DGGE fingerprints demonstrated that NPK, calcium ammonium nitrate and poultry droppings selected different bacterial populations during the active phase of oil degradation. Cluster analysis of DGGE bands using simple matching group average setting revealed that poultry droppings-amended soils and calcium ammonium nitrateamended soils formed distinct clades meaning that the treatment selected similar bacterial populations for each of the treatments whereas NPK soils showed less association. Excision, reamplification and sequencing of dominant DGGE bands in biostimulated soils revealed the presence of distinct hydrocarbon degraders like Corynebacterium spp., Dietzia spp., low G+C Gram positive bacteria and some uncultured bacterial clones. Phylogenetic analysis of the $16 \mathrm{~S}$ rRNA gene sequences of these dominant bacterial communities was conducted using the neighbour joining method of PHYLIP. Two distinct clades appeared in the tree clustered members of the Actinobacteria and Firmicutes separately. The overall data suggested that Gram positive bacteria especially members of the Actinobacteria may have a key role in bioremediation of crude oil-polluted soil.
\end{abstract}

Keywords: Bacterial dynamics; Arabian light crude oil; bioremediation; phylogenetic analysis; PHYLIP. 
CHIKERE, C. B; SURRIDGE, K. J; CLOETE, T. E; OKPOKWASILI, G. C. Phylogenetic diversity of dominant bacterial communities during bioremediation of crude oil-polluted soil. Ambi-Agua, Taubaté, v. 6, n. 2, p. 61-76, 2011. (doi:10.4136/ambi-agua.186)

\section{Diversidade filogenética de comunidades bacterianas dominantes durante a biorremediação do solo de óleo bruto poluído}

\section{RESUMO}

A biorremediação de hidrocarbonetos poluentes é vantajosa devido à relação custobenefício da tecnologia e da ubiqüidade dos microrganismos degradadores de hidrocarbonetos no solo. A diversidade microbiana do solo é afetada pela perturbação gerada por hidrocardonetos, ocasionando assim o enriquecimento seletivo dos microrganismos utilizadores destes hidrocarbonetos. Os hidrocarbonetos interagem com a matriz do solo e a microbiota, determinando o destino dos contaminantes em relação à sua natureza química e à capacidade de degradação da comunidade microbiana, respectivamente. A dinâmica bacteriana nos microcosmos contaminados por petróleo e submetidos à biorremediação foi investigada por um período de 42 dias. Quatro dos cinco microcosmos contendo solo não poluído foram contaminados com $4 \%$ de petróleo. Três microcosmos contaminados por petróleo foram corrigidos com $25 \mathrm{~g}$ do fertilizante NPK, nitrato de amônia e cálcio e excrementos de aves, respectivamente; enquanto no quarto microcosmo contaminado por petróleo nada foi adicionado. O quinto microcosmo consistia apenas de solo puro (não contaminado por petróleo) e foi utilizado para a averiguação da estrutura da comunidade microbiana indígena do solo. Os solos bioestimulados foram periodicamente cultivados e irrigados. A degradação dos hidrocarbonetos foi quantificada por cromatografia gasosa durante todo o período experimental. O rastreamento por cromatografia gasosa dos hidorcarbonetos residuais nos solos bioestimulados indicaram significativa atenuação dos contaminantes a partir da segunda semana (dia 14) até a sexta semana (dia 42) após a contaminação, enquanto no solo controle contaminado por petróleo, nenhum pico significativo de redução de hidrocarbonetos foi verificado durante todo o período experimental. A caracterização molecular das comunidades bacterianas envolvidas na biodegradação aeróbia de hidrocarbonetos do petróleo nos solos bioestimulados e nos controles foi gerada pela técnica de DGGE, utilizando produtos de amplificação por PCR do gene 16S rRNA obtido pela extração do DNA total do solo. Os padrões obtidos pelo DGGE demonstraram que a bioestimulação causada pela fertilização com NPK, nitrato de amônio e cálcio, e excrementos de aves selecionaram populações bacterianas diferentes durante a fase ativa da degradação do petróleo. A análise do agrupamento de bandas do DGGE utilizando a média simples de correspondência de grupo revelou que a adição de nitrato de amônio e cálcio, e excrementos de aves aos solos formaram clados distintos, o que significa que estes tratamentos selecionaram populações características de bactérias para cada tratamento, enquanto os solos tratados com NPK mostraram menor associação. A excisão, reamplificação e sequenciamento de bandas dominantes no DGGE nos solos bioestimulados revelaram a presença de distintos microrganismos degradadores de hidrocarbonetos, como o Corynebacterium spp., Dietzia spp., bactérias de baixo G+C Gram-positivas e alguns clones bacterianos não cultivados. Análises filogenéticas das sequências do gene 16S rRNA das comunidades bacterianas dominantes foram realizadas utilizando-se o método "neighbor joining" do programa PHYLIP. Dois clados distintos foram observados na árvore do agrupamento, membros do cluster Actinobacteria e Firmicutes, separadamente. Dados globais sugerem que bactérias Gram-positivas, especialmente membros de Actinobacteria podem ter um papel fundamental na biorremediação de solos poluídos por petróleo.

Palavras-chave: dinâmica bacteriana; petróleo bruto leve da Arábia; biorremediação; análise filogenética; PHYLIP. 
CHIKERE, C. B; SURRIDGE, K. J; CLOETE, T. E; OKPOKWASILI, G. C. Phylogenetic diversity of dominant bacterial communities during bioremediation of crude oil-polluted soil. Ambi-Agua, Taubaté, v. 6, n. 2, p. 61-76, 2011. (doi:10.4136/ambi-agua.186)

\section{INTRODUCTION}

Crude oil pollution is widespread in the environment and at present is a serious ecological problem facing the oil-rich Niger Delta region of Nigeria. Over $80 \%$ of Nigeria's oil comes from this zone and its surrounding offshore area (Okpokwasili and Odokuma, 1994; Okpokwasili, 2006). Within the Delta, the numerous tank farms, flow stations, pipelines, tankers and loading jetties provide a constant threat of oil pollution (Ijah and Antai, 2003a,b; Nweke and Okpokwasili, 2004; Chikere and Chijioke-Osuji, 2006). Bioremediation which is the application of the metabolic capacity of biological systems (plants and microbes) to degrade hazardous substances into less toxic or innocuous ones in the environment has gained popularity in the global conservation and environmental sustainability strategies. It is a natural process that takes advantage of nature's recycling and self-purification capabilities and as such is accepted by the public for cleanup of polluted ecosystems (Kaplan and Kitts, 2004; Nweke and Okpokwasili, 2004; Van Elsas et al., 2007; Chikere et al., 2009a,b,c).

The goal of bioremediation is to degrade pollutants to concentrations that are either undetectable or to those below the levels prescribed by regulatory agencies like United States Environmental Protection Agency (US EPA), Federal Ministry of Environment (FME) and various State Environmental Protection Agencies in Nigeria. Bioremediation is a preferred treatment technology for the decontamination of hydrocarbon-polluted soils (Van Hamme et al., 2003; Maila et al., 2005) and several studies have underscored the effectiveness and ecofriendliness of this technology in different geographical and ecological contexts (Macnaughton et al., 1999; Zucchi et al., 2003; Kaplan and Kitts, 2004; Philp et al., 2005; Hamamura et al., 2006; Margesin et al., 2007; Stroud et al., 2007; Quatrini et al., 2008). It is also well documented that hydrocarbon-utilizing bacteria are ubiquitous in both contaminated and pristine soils (Leahy and Colwell, 1990; Bundy et al., 2002, 2004; Van Beilen and Funhoff, 2005, 2007). The existence of microorganisms with the required catabolic activities is necessary for efficient bioremediation. In addition, the polluting compound must be accessible or bioavailable, to the degrading microorganisms in the soil. Environmental and nutritional conditions favourable for prolific microbial activities and the absence of inhibitory substances are also essential (Van Elsas et al., 2007). Three types of bioremediation are predominant in the industry today including natural attenuation, biostimulation and bioaugmentation (Van Hamme et al., 2003). The simplest method is natural attenuation, where contaminated soils are only monitored for contaminant concentration to assure regulators that natural processes of contaminant degradation are active. Biostimulation is the process of providing microbial communities with a favourable environment in which they can effectively degrade contaminants and in most cases involves the provision of rate-limiting resources like nitrogen, phosphorus and oxygen to speed up the bioremediation process (Rosenberg et al., 1996; Kaplan and Kitts, 2004; Roling et al., 2002, 2004). Crude oil and other petroleum hydrocarbons are chemically heterogeneous and almost ubiquitous in the environment. Not only are they found at the site of oil pollution, but chemical analysis has revealed the presence of both aliphatic and aromatic hydrocarbons, in most pristine soils and sediments (Heiss-Blanquet et al., 2005; Ollivier and Magot, 2005; Philp et al., 2005; Kloss et al., 2006; Quatrini et al., 2008). The probable origins of these low concentrations of hydrocarbons in pristine environmental media are seepage from natural deposits and biosynthesis by plants and microorganisms (Atlas and Philp, 2005; Ollivier and Magot, 2005). It is therefore not surprising that hydrocarbon utilizing bacteria (HUB) are widely distributed in nature. Several investigations have demonstrated an increase in numbers of HUB in oilpolluted habitats undergoing bioremediation (Rosenberg et al., 1992, 1996; Rosenberg and Ron, 1996; Bouchez-Naitali et al., 1999; Macnaughton et al., 1999; Williams et al., 1999; Odokuma and Ibor, 2002; Margesin et al., 2003; Odokuma and Dickson, 2003; Koren et al., 
CHIKERE, C. B; SURRIDGE, K. J; CLOETE, T. E; OKPOKWASILI, G. C. Phylogenetic diversity of dominant bacterial communities during bioremediation of crude oil-polluted soil. Ambi-Agua, Taubaté, v. 6, n. 2, p. 61-76, 2011. (doi:10.4136/ambi-agua.186)

2003; Sei et al., 2003; Siciliano et al., 2003; Bordenave et al., 2004; Chikere and ChijiokeOsuji, 2006; Hamamura et al., 2006; Ruberto et al., 2006; Rojas-Avelizapa et al., 2007; Quatrini et al., 2008). However, previous and recent works have suggested that despite an increase in the HUB percentage, the biodiversity of the bacterial community may be dramatically reduced since the presence of hydrocarbons in the environment often leads to selective enrichment of HUB, to the relative detriment of biodiversity (Leahy and Colwell, 1990; Rosenberg and Ron, 1996; Abed et al., 2002; Evans et al., 2004; Atlas and Philp, 2005; Maila et al., 2005; Hamamura et al., 2006; Popp et al., 2006; Quatrini et al., 2008; Rodrigues et al., 2009). In order to achieve hydrocarbon utilization by bacteria, a number of rate limiting nutritional requirements need to be provided. Hydrocarbons as their name implies are composed of hydrogen and carbon; therefore there is a need to supply all other elements essential for growth in the growth medium (Philp et al., 2005). These growth factors include molecular oxygen for the oxygenases, nitrogen, phosphorus, sulphur and metals like $\mathrm{K}^{+}$and $\mathrm{Na}^{+}$(Leahy and Colwell, 1990; Rosenberg et al., 1996; Van Hamme et al., 2003; Ollivier and Magot, 2005). Traditionally, characterization of microbial community composition in contaminated soil has been limited to the ability to culture microorganisms from environmental samples. Unfortunately, only a fraction of the microorganisms involved in the biodegradation of contaminants in soil can currently be cultured in the laboratory (Malik et al., 2008). It is estimated that more than $90 \%$ of species making up the microbiota in the environment do not form colonies when cultured using conventional techniques (Macnaughton et al., 1999; Theron and Cloete, 2006; Quatrini et al., 2008). Through the use of culture-independent methods such as nucleic acid-based techniques, polymerase chain reaction (PCR)-amplification of 16S rRNA genes, denaturing gradient gel electrophoresis(DGGE)and phylogenetic analytical software and programmes, new insights have been gained into the composition of both culturable and non culturable microbial communities in hydrocarbon-polluted soils during bioremediation (Macnaughton et al., 1999; Margesin et al., 2003; Sei et al., 2003; Maila et al., 2005; Surridge et al., 2005; Hamamura et al., 2006; Smalla et al., 2007; Chikere et al., 2008, 2009c; Malik et al., 2008; Quatrini et al., 2008; Kumar and Khana, 2010; Lal et al., 2010).

The objectives of the present investigation were to identify key bacterial populations that are involved in crude oil degradation using molecular fingerprinting methods (PCR, DGGE) and also ascertain the phylogeny of 16S rRNA sequences corresponding to dominant DGGE bands by constructing phylogenetic tree using the neighbour joining method of phylogenetic inference package (PHYLIP).

\section{MATERIALS AND METHODS}

\subsection{Sample preparation}

Soil (85\% sand, $10 \%$ clay and $5 \%$ silt) with $\mathrm{pH} 5.3$, was collected from the surface horizon (A horizon) and divided into fifteen $5 \mathrm{~L}$ pots each containing $4 \mathrm{~kg}$ of soil. The pots which had openings at the base were in triplicates to represent five different treatment regimens namely NPK amended soil (PN), calcium ammonium nitrate amended soil (PU), poultry droppings amended soil (PP), oil-contaminated control (OC) and pristine control (PC). All treatments except PC were contaminated with 4\% (w/v) of Arabian light crude oil. The oil contaminated soil samples were thoroughly mixed with a hand trowel sanitized with $70 \%$ ethanol. For the nutrient amended soils, $25 \mathrm{~g}$ of NPK, calcium ammonium nitrate or poultry droppings was dissolved in $200 \mathrm{ml}$ sterile distilled water and mixed with the contaminated soil to distribute the crude oil and nutrients through the soil particles and also to enhance aeration. Microcosms were kept at room temperature in a green house; nutrient treated soils were regularly watered weekly with $200 \mathrm{ml}$ sterile distilled water to compensate 
CHIKERE, C. B; SURRIDGE, K. J; CLOETE, T. E; OKPOKWASILI, G. C. Phylogenetic diversity of dominant bacterial communities during bioremediation of crude oil-polluted soil. Ambi-Agua, Taubaté, v. 6, n. 2, p. 61-76, 2011. (doi:10.4136/ambi-agua.186)

for evaporated water and also mixed every other day for aeration. The oil-contaminated and pristine controls were left undisturbed throughout the 6-week experimental period. The microcosms were sampled at days zero, 7, 14, 21, 28, 35 and 42. Triplicate microcosms were sampled for each treatment and bulked to obtain a composite sample.

\subsection{Gas chromatographic analysis}

Hydrocarbon degradation/loss in the biostimulated and control soils was determined by extracting residual hydrocarbons from PN, PU, PP and OC microcosms weekly starting from day zero of experiment. Five grams of soil was mixed with $40 \mu \mathrm{l}$ of n-pentane (HPLC grade) to which $32 \mu$ of Cumene (Isopropyl benzene) was added as internal standard. The analysis was carried out using a Varian 1440 GC-FID (California, USA). A DB-1 column was used with the following dimensions: $30 \mathrm{~m} \times 0.2 \mathrm{~mm} ; 0.25 \mu \mathrm{m}$ film thickness; 0.32 i.d. Helium was the carrier gas at a flow rate of $1 \mathrm{ml} / \mathrm{min}$. Analyses were carried out in split injection mode using a split ratio 5:1. The injection port was set at $250^{\circ} \mathrm{C}$. The oven temperature was programmed from $40^{\circ} \mathrm{C}$ for $10 \mathrm{~min}$, then $20^{\circ} \mathrm{C}$ per min to $330^{\circ} \mathrm{C}$, holding this temperature for $10 \mathrm{~min}$.

\subsection{Molecular analysis}

Total microbial community DNA from microcosms corresponding to the five treatments was extracted with Zymo Research Soil Microbe DNA kit (Inqaba Biotech, SA) and Bio 101 FP-120 FastPrep cell disruptor (Qbiogene, Inc. Canada). PCR was done according to Surridge (2005) as described briefly. Amplification of the template DNA was performed using $2 \mu \mathrm{l}$ volume of the extracted DNA with Bio Rad MJ Mini thermal cycler (Mexico). The $50 \mu \mathrm{l}$ PCR mixture contained $5 \mu \mathrm{l}$ of deoxy nucleoside triphosphates (dNTPs) mixture $(2.5 \mu \mathrm{M})($ Promega, USA), $5 \mu \mathrm{l}$ of 5X Green Go Taq Flexi buffer (Promega, USA), $3.5 \mu \mathrm{l}$ of $25 \mathrm{mM}$ $\mathrm{MgCl}_{2}$ (Promega, USA), $2 \mu \mathrm{l}$ each of $10 \mathrm{pmol}$ of both forward (primer $\mathrm{M}$ ) and reverse (primer K) primers pA8f-GC (5'-CGC-CCG-CCG-CGC-GCG-GCG-GCG-GGC-GGG-GCG-GGG-GCAGGG-GAG-AGT-TTG-ATC-CTG-GCT-CAG-3') and KPRUN518r (5'-ATTACCGCGGCTGCTGG3'), $0.25 \mu \mathrm{l}$ of $5 \mathrm{U} / \mu \mathrm{l}$ hot start Go Taq DNA polymerase, $2.5 \mu \mathrm{l}$ of $20 \mathrm{mg} / \mathrm{ml}$ of bovine serum albumin and $27.75 \mu \mathrm{l}$ of sterile water. A reaction tube without template DNA was included as negative control. The PCR programme was as follows: denaturing step at $95^{\circ} \mathrm{C}$ for $3 \mathrm{~min}$, followed by 33 cycles of 30 sec at $95^{\circ} \mathrm{C}$, annealing for $30 \mathrm{sec}$ at $55^{\circ} \mathrm{C}$ and extension at $72^{\circ} \mathrm{C}$ for $1 \mathrm{~min}$, followed by a final extension at $72^{\circ} \mathrm{C}$ for $7 \mathrm{~min}$ and then held at $4^{\circ} \mathrm{C}$. Amplified DNA was examined by electrophoresis in 1.4\% agarose gel with $2 \mu \mathrm{l}$ aliquots of PCR products in $1 \mathrm{X}$ Tris-Acetate-EDTA buffer using Bio Rad Power $\mathrm{Pac}^{\mathrm{TM}}$ electrophoretic machine while DGGE was done according to Muyzer et al. (1993) using BioRad Dcode Multi Mutation Detection System as described briefly. Ten microlitres containing 250ng of the various 16S PCR products were loaded per lane onto 25-55 \% denaturing gradient gels. Gels were run at $70 \mathrm{~V}$ for $17 \mathrm{~h}$ at a constant temperature of $60{ }^{\circ} \mathrm{C}$. Image analysis was performed using the Gel2K (Norland, 2004) programme and fingerprints were analysed in a cluster investigation using CLUST (Norland, 2004). PCR products of excised dominant bands were sequenced using an ABI 3130XL genetic analyzer (Applied Biosystems, Foster City, CA) incorporating the ABI Big Dye Terminator Cycle Sequencing kit version 3.1 (Applied Biosystems, Foster City, CA). Sequence identification was performed using the BLAST-N facility of the National Center for Biotechnology Information (NCBI http://www.ncbi.nlm.nih.gov) while phylogenetic analysis was performed using the neighbour joining method of PHYLIP. All the sequences obtained in the study have been deposited with GenBank under accession numbers GU451069 to GU451108. 
CHIKERE, C. B; SURRIDGE, K. J; CLOETE, T. E; OKPOKWASILI, G. C. Phylogenetic diversity of dominant bacterial communities during bioremediation of crude oil-polluted soil. Ambi-Agua, Taubaté, v. 6, n. 2, p. 61-76, 2011. (doi:10.4136/ambi-agua.186)

\section{RESULTS AND DISCUSSION}

The bacterial populations associated with aerobic degradation of crude oil as examined by analysis of PCR-amplified 16S rRNA gene fragments using DGGE are shown in Figure 1. DNA samples used for DGGE were taken from the days when appreciable reduction in hydrocarbons peaks was demonstrated in the chromatograms (data not shown). All nutrientamended treatments showed emergence of prominent DGGE bands during the experimental period. Banding patterns showed that dominant DGGE bands appeared in nutrient amended soils PN, PU, PP over time (0-42 days) and not in the pristine or oil contaminated controls (PCB, OCB, OC0, OC42).

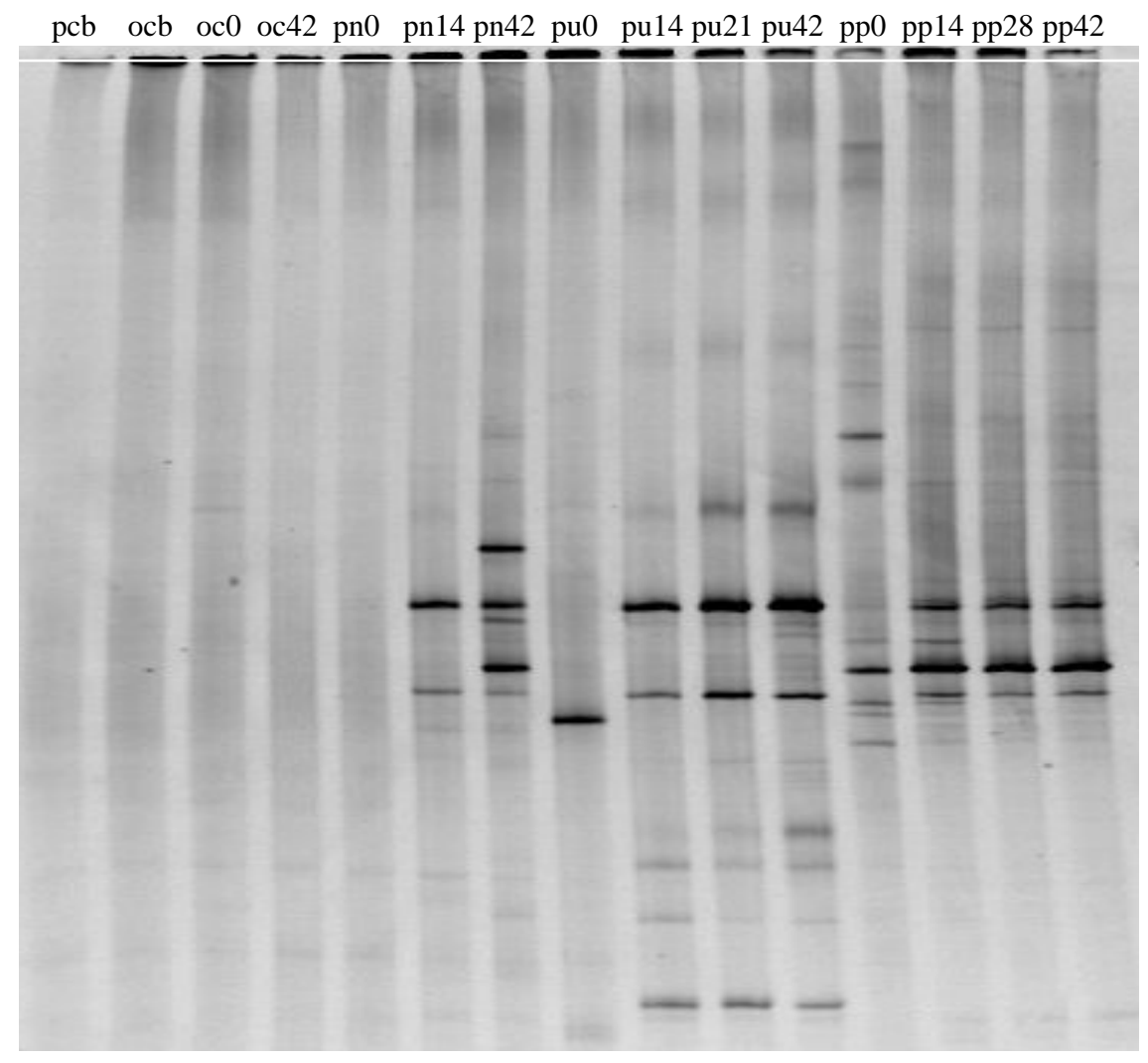

Figure 1. DGGE profiles of $16 \mathrm{~S}$ rRNA gene fragments from pcb, pristine control baseline; ocb, oil-contaminated control baseline; oc0, oilcontaminated control zero day; oc42, oil-contaminated control $42^{\text {nd }}$ day and nutrient amended soils pn0, NPK-amended soil day0; pn14, NPKamended soil day14; pn42, NPK-amended soil day42; pu0, calcium ammonium nitrate-amended soil day0; pu14, calcium ammonium nitrateamended soil day14; pu21, calcium ammonium nitrate-amended soil day21; pu42, calcium ammonium nitrate-amended soil day42; pp0, poultry droppings-amended soil day0; pp14, poultry droppings-amended soil day14; pp28, poultry droppings-amended soil day28; pp42, poultry droppings-amended soil day42.

In PN soil, no dominant bands were observed on day zero (pn0) of the experiment, but a prominent band appeared on day 14 and persisted till day 42. All nutrient amended soils showed obvious successional patterns, where most DGGE bands emerging early in the experiment disappeared with time as others that appeared later remained relatively prominent throughout the study period. Conversely, no obvious changes in DGGE banding patterns were observed in the oil contaminated control (oc0 and oc42) during the experimental period. 
CHIKERE, C. B; SURRIDGE, K. J; CLOETE, T. E; OKPOKWASILI, G. C. Phylogenetic diversity of dominant bacterial communities during bioremediation of crude oil-polluted soil. Ambi-Agua, Taubaté, v. 6, n. 2, p. 61-76, 2011. (doi:10.4136/ambi-agua.186)

Consequently, the populations corresponding to the prominent DGGE bands in nutrient amended soils were clearly due to biostimulation rather than oil contamination alone. Species diversity, and to certain extent species richness, as derived from the DGGE gel by compiling a dendogram (cluster analysis) using simple matching - group average setting of the CLUST software is shown in Figure 2. The programme CLUST (Norland, 2004) is based on Shannon index algorithms and groups the profiles of the species in each sample according to how similar in community composition the samples are. Thus, samples from similar environments would be expected to display analogous communities and group together in the CLUST dendogram. Two main clades were observed with the simple matching algorithm comprising (1) pristine control soil baseline (PCB), NPK-amended soil days 0 (PN0) and 14 (PN14), oilcontaminated soil baseline (OCBl), oil contaminated control day42 (OC42), calcium ammonium nitrate-amended soil days 0 (PU0), 14 (PU14), 21 PU21), 42 (PU42) and (2) oilcontaminated control day 0 (OC0I), NPK-amended soil day 42 (PN42D) poultry droppingsamended soil days 0 (PP0D), 14 (PP14D), 28 (PP28D) and 42 (PP42D). Thus, all poultry droppings amended samples clustered together which meant that the treatment selected similar bacterial groups involved in crude oil biodegradation during the period studied. Calcium ammonium nitrate samples (PU) on days 14, 21 and 42 also formed a distinct cluster which showed that the treatment given to the sample resulted in the selection of a similar genetic community profile across the days DNA samples were extracted from the PU soil. NPK-amended soil (PN) on days 0 and 14 clustered together with pristine control (PCB) while PN42 clustered with oil-contaminated control day 0 (OCOI). Oil-contaminated control baseline (OCBl) clustered with calcium ammonium nitrate soil day 0 (PUOD).

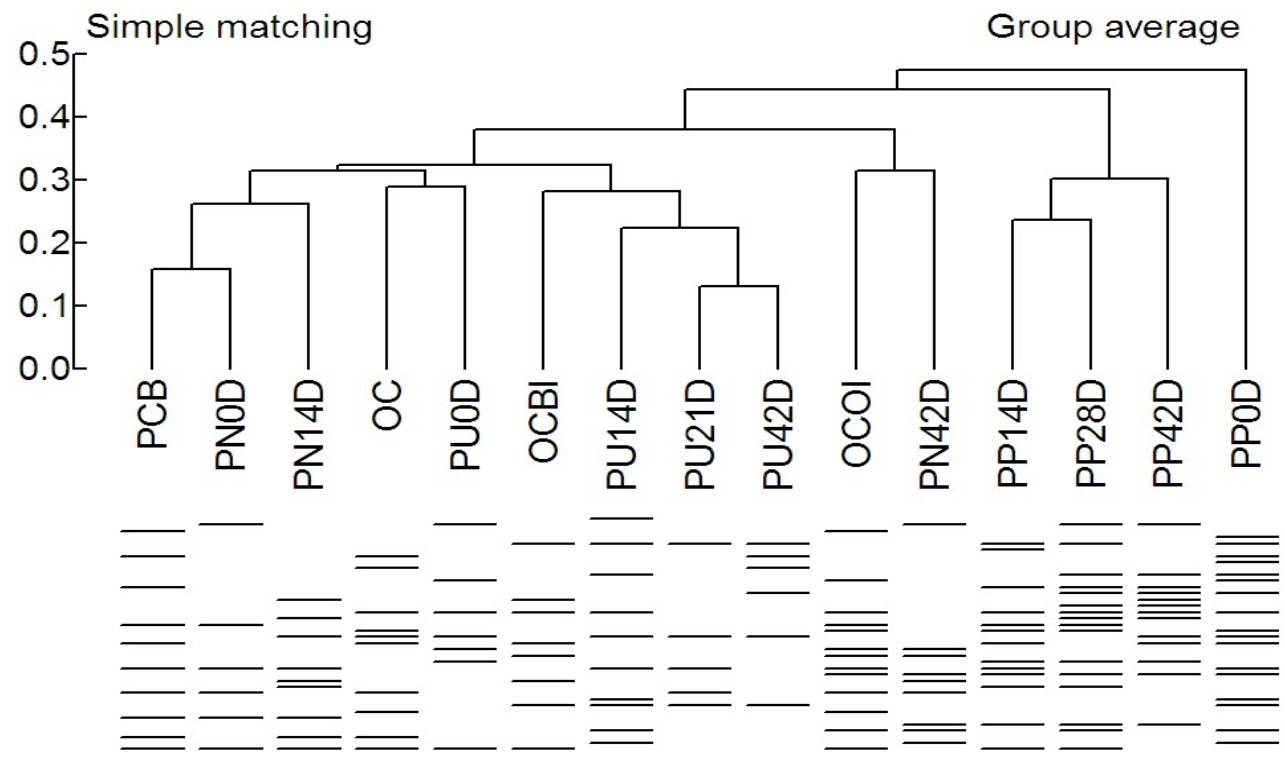

Figure 2. Cluster analysis of the banding pattern in Figure 1 using a simple matching group average setting to separate communities according to species sequence differences. PCB: pristine soil baseline; PNOD: NPK-amended soil day 0; PN14: NPK-amended soil day 14; OC: oil-contaminated control soil day 42; PU0: calcium ammonium nitrate-amended soil day 0; OCBI: oil-contaminatedcontrol baseline; PU14D: calcium ammonium nitrate-amended soil day 14; PU21D: calcium ammonium nitrate-amended soil day 21; PU42D: calcium ammonium nitrate-amended soil day 42; OCOI: oil-contaminated control soil day 0; PN42D: NPK-amended soil day 42; PP14D: poultry dropping-amended soil day 14; PP28D: poultry dropping-amended soil day 28; PP42D: poultry dropping-amended soil day 42; PP0D: poultry dropping-amended soil day 0 . Scale on y axis represents the evolutionary distance between tree branches and nodes in increments of 0.1 . 
CHIKERE, C. B; SURRIDGE, K. J; CLOETE, T. E; OKPOKWASILI, G. C. Phylogenetic diversity of dominant bacterial communities during bioremediation of crude oil-polluted soil. Ambi-Agua, Taubaté, v. 6, n. 2, p. 61-76, 2011. (doi:10.4136/ambi-agua.186)

Phylogenetic relationships of 16S rRNA sequences obtained from dominant DGGE bands were done using PHYLIP (phylogenetic inference package) version 3.67. Phylogenetic tree shown in Figure 3 was constructed using the neighbour joining method, distance matrixes were calculated by Jukes and Cantor Model for single nucleotide substitution. Sequencing revealed that dominant bacterial populations in the biostimulated treatments were mainly Gram positive bacteria which comprised Corynebacterium spp., Dietzia spp., Low G+C Gram positive bacteria, uncultured bacterial clones and Rhodococcus sp. The numbers in the tree branches represent the dominant DGGE bands while the maximum identities of these DGGE bands to their GenBank closest relatives are presented in percentage.

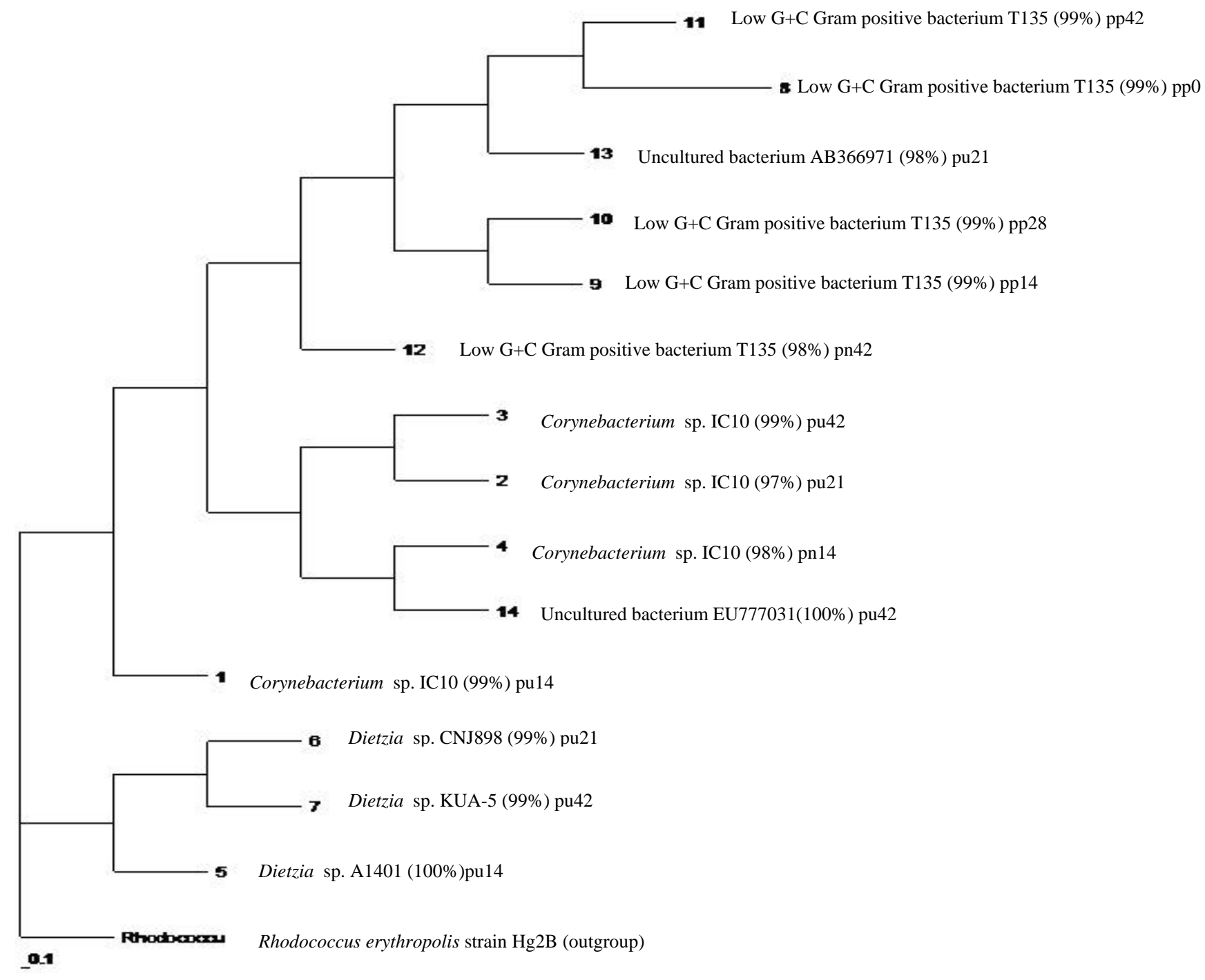

Figure 3. Phylogenetic relationships of dominant 16S rRNA sequences from different nutrientamended treatments in Figure 1 using PHYLIP version 3.67. Phylogenetic tree was constructed using the neighbour joining method, distance matrixes were calculated by Jukes and Cantor Model for single nucleotide substitution per sequence represented by a scale of 0.1 at the foot of the tree. The tree was rooted with the 16S rRNA gene sequence of Rhodococcus erythropolis strain Hg2B, a hydrocarbon degrading bacterium. Percentage represents maximum identity score to GenBank closest relative. The numbers 1-14 represent 16S rRNA sequences of the dominant DGGE bands shown in Figure 1 and their maximum identity with closest GenBank relatives are enclosed in parentheses as percentages.

It is an established scientific fact that hydrocarbon utilizing bacteria proliferate in a given environment following anthropogenic and natural release of crude oil and other hydrocarbons 
CHIKERE, C. B; SURRIDGE, K. J; CLOETE, T. E; OKPOKWASILI, G. C. Phylogenetic diversity of dominant bacterial communities during bioremediation of crude oil-polluted soil. Ambi-Agua, Taubaté, v. 6, n. 2, p. 61-76, 2011. (doi:10.4136/ambi-agua.186)

(Leahy and Colwell, 1990). PN treatment showed the greatest decrease of the pollutants by day 14 followed by PU and PP by day 21 respectively. It was observed that almost all the hydrocarbons in the amended soils were degraded three weeks post-oil contamination as revealed by gas chromatography. By day 42, the heights of the hydrocarbon peaks were all reduced in the nutrient amended soils in this order, $\mathrm{PN}>\mathrm{PU}>\mathrm{PP}$ whereas no noticeable decrease was observed in the oil contaminated control (OC). Throughout the 42-day period, PN (NPK amended soil) showed the most effective degradation of the crude oil. The bacterial counts however did not reflect these trends as PP (poultry droppings amended soil) showed the highest counts for both THB and HUB (data not shown). Poultry litter has been shown to contain a large number of microorganisms (Williams et al., 1999; Ijah and Antai, 2003a) which may have been an added inoculum to the ones already in the soil as also recorded in this study. In the same vein, Van Hamme et al. (2003) reported that mineral salts medium used in the isolation of HUB can favour even non degrading microbes because of traces of carbon in agar thereby overestimating their numbers and importance during bioremediation. Hamamura et al. (2006) in their study also reported cultivation of numerous HUB from oilcontaminated soil which did not correlate with the results obtained using culture-independent molecular techniques and advised that molecular methods should be used to confirm and verify results obtained using traditional cultivation methods. Culture-dependent methods have been used by several researchers to isolate bacteria involved in the degradation of petroleum hydrocarbons (Odokuma and Dickson, 2003; Chaillan et al., 2004; Nweke and Okpokwasili, 2004; Ebuehi et al., 2005; Maila et al., 2005; Ayotamuno et al., 2006; Chikere and ChijiokeOsuji; 2006; Adoki and Orugbani, 2007; Rojas-Avelizapa et al., 2007), even though only a fraction of soil bacteria involved in biodegradation can currently be cultured in the laboratory (Surridge et al., 2005; Malik et al., 2008; Zengler, 2008; Heinzel et al., 2009). It was observed that total culturable heterotrophic and hydrocarbon utilizing bacterial counts increased in the biostimulated soils (PN, PU and PP) starting from days 7 and 21 reaching the highest numbers by days 35 and 42 respectively. On the other hand, populations of both culturable heterotrophic and hydrocarbon utilizing bacterial counts remained stable throughout the experimental period in the oil-contaminated and pristine control soils (OC and PC). Several studies have also recorded an increase in culturable heterotrophic and hydrocarbon utilizing bacterial counts during crude oil biodegradation following biostimulation (Margesin et al., 2003; Chaillan et al., 2004; Nweke and Okpokwasili, 2004; Ebuehi et al., 2005; Ayotamuno et al., 2006; Chikere and Chijioke-Osuji, 2006). Changes in bacterial counts detected in all biostimulated soils were induced by the addition of nutrients rather than oil contamination alone. The same observation was made by Evans et al. (2004) when they investigated the impact of oil contamination and biostimulation on the diversity of indigenous bacterial communities in soil microcosms. The most consistent pattern observed in the present study was the emergence of Corynebacterium sp. IC10-like bacteria in all nutrient-amended soils treated with different organic and inorganic nutrients. Wide distribution of these bacterial species in the biostimulated soils indicates the importance of Corynebacterium spp. in hydrocarbon degradation. This finding is consistent with results from previous studies showing the prevalence of hydrocarbon-degrading Corynebacterium spp. in various hydrocarbon-contaminated soils using culture-dependent (Bouchez-Naitali et al., 1999; Rahman et al., 2002; Adebusoye et al., 2007 ) and culture-independent approaches (Jimenez et al., 2007). Electron microscopy (electron micrographs not shown) also revealed the abundance of Corynebacterium spp. in consortia across all nutrient-amended treatments which confirmed the results obtained from the sequencing study which revealed prevalence of Corynebacterium sequences. The phylogenetic tree comprised two distinct clades which clustered members of the Actinobacteria and Firmicutes separately. These Gram positive bacteria have been shown by independent researches to contain hydrocarbon degrading species (Okpokwasili et al., 1986; Ollivier and Magot, 2005; Hamamura et al., 2006; Van 
CHIKERE, C. B; SURRIDGE, K. J; CLOETE, T. E; OKPOKWASILI, G. C. Phylogenetic diversity of dominant bacterial communities during bioremediation of crude oil-polluted soil. Ambi-Agua, Taubaté, v. 6, n. 2, p. 61-76, 2011. (doi:10.4136/ambi-agua.186)

Beilen and Funhoff, 2007; Quatrini et al., 2008) and it may be that species of these bacteria detected in the study could as well be hydrocarbon degraders.

\section{CONCLUSION}

It could be inferred that bacterial population changes occurred as a result of biostimulation. Nutrient input, aeration and watering enhanced biodegradation capabilities of the autochthonous bacterial populations. Denaturing gradient gel electrophoresis of PCRamplified 16S rRNA gene used in this study provided a rapid and efficient cultureindependent approach to elucidate the bacterial diversity, community structure and phylogeny during bioremediation. This technique demonstrated that members of the Actinobacteria phylogenetic group were the dominant bacteria involved in crude oil biodegradation after biostimulation with different nutrient sources as measured using molecular fingerprinting method. From the gas chromatographic tracing, NPK fertilizer seems to be the best nutrient for the biostimulation of indigenous bacterial community in crude oil-polluted soil and concomitant degradation of hydrocarbons.

\section{ACKNOWLEDGEMENT}

This work was generously funded by Organization for Women in Science for the Developing World (OWSDW) formerly Third World Organization for Women in Science (TWOWS) postgraduate fellowship given to the corresponding author.

\section{REFERENCES}

ABED, R. M.; SAFI, N. M.; KOSTER, J.; DE BEER, D.; EL-NAHHAL, Y.; RULLKOTTER, J. et al. Microbial diversity of a heavily polluted microbial mat and its community changes following degradation of petroleum compounds. Applied and Environmental Microbiology, v. 68, p. 1674-1683, 2002. http://dx.doi.org/10.1128/AEM.68.4.1674-1683.2002

ADEBUSOYE, S. A.; ILORI, M. O.; AMUND, O. O.; TENIOLA, O. D.; OLATOPE, S. O. Microbial degradation of petroleum hydrocarbons in a polluted tropical stream. World Journal of Microbiology and Biotechnology, v. 23, p. 149-1159, 2007. http://dx.doi.org/10.1007/s11274-007-9345-3

ADOKI, A.; ORUGBANI, T. Removal of crude petroleum hydrocarbons by heterotrophic bacteria in soils amended with nitrogenous fertilizer plant effluents. African Journal of Biotechnology, v. 6, p. 1529-1535, 2007.

ATLAS, R. M.; PHILP, J. Bioremediation: applied microbial solutions for Real-World Environmental Cleanup. Washington, DC: American Society for Microbiology (ASM) Press, 2005. p. 78-105.

AYOTAMUNO, M. J.; KOGBARA, R. B.; OGAJI, S. O. T.; POBERT, S. D. Bioremediation of a crude oil polluted agricultural soil in Port Harcourt, Nigeria. Applied Energy, v. 83, p. 1249-1257, 2006. http://dx.doi.org/10.1016/j.apenergy.2006.01.003

BORDENAVE, S.; FOURCANS, A.; BLANCHARD, S.; GONI, M. S.; CAUMETTE, P.; DURAN, R. Structure and functional analyses of bacterial communities changes in microbial mats following petroleum exposure. Ophelia, v. 58, p. 195-203, 2004. 
CHIKERE, C. B; SURRIDGE, K. J; CLOETE, T. E; OKPOKWASILI, G. C. Phylogenetic diversity of dominant bacterial communities during bioremediation of crude oil-polluted soil. Ambi-Agua, Taubaté, v. 6, n. 2, p. 61-76, 2011. (doi:10.4136/ambi-agua.186)

BOUCHEZ-NAITALI, M.; RAKATOZAFY, H.; MARCHALS, R.; LEVEAU, J. V.; VANDECASTEELE, J. P. Diversity of bacterial strains degrading hexadecane in relation to the mode of substrate uptake. Journal of Applied Microbiology, v. 86, p. 421-428, 1999. http://dx.doi.org/10.1046/j.1365-2672.1999.00678.x

BUNDY, J. G.; PATON, G. I.; CAMPBELL, C. D. Microbial communities in different soil types do not converge after diesel contamination. Journal of Applied Microbiology, v. 92, p. 976-288, 2002. http://dx.doi.org/10.1046/j.1365-2672.2002.01528.x

BUNDY, J. G.; PATON, G. I.; CAMPBELL, C. D. Combined microbial community level and single species biosensor responses to monitor recovery of oil polluted soil. Soil Biology and Biochemistry, v. 36, p. 1149-1159, 2004.

http://dx.doi.org/10.1016/j.soilbio.2004.02.025

CHAILLAN, F.; LE FLECHE, A.; BURY, E.; PHANTAVONG, Y.; GRIMONT, P.; SALIOT, A. et al. Identification and biodegradation potential of tropical aerobic hydrocarbon-degrading microorganisms. Research in Microbiology, v. 155, p. 587595, 2004. http://dx.doi.org/10.1016/j.resmic.2004.04.006

CHIKERE, C. B.; OKPOKWASILI, G. C.; SURRIDGE, A. K. J.; CLOETE, T. E. Impact of oil contamination and biostimulation on bacterial diversity in soil microcosms. In: INTERNATIONAL HSE BIENNIAL CONFERENCE ON THE OIL AND GAS INDUSTRY IN NIGERIA, 3-5 oct. 2008, Abuja. Proceedings... Abuja: DPR, 2008. p. $1-7$.

CHIKERE, C. B.; OKPOKWASILI, G. C.; CHIKERE, B. O. Bacterial diversity in a tropical crude oil-polluted soil undergoing bioremediation. African Journal of Biotechnology, v. 8, p. 2535-2540, 2009a.

CHIKERE, C. B.; OKPOKWASILI, G. C.; ICHIAKOR, O. Characterization of hydrocarbon utilizing bacteria in tropical marine sediments. African Journal of Biotechnology, v. 8, p. 2541-2544, 2009b.

CHIKERE, C. B.; OKPOKWASILI, G. C.; SURRIDGE, A. K. T.; CLOETE, T. E. Molecular approach to aerobic biodegradation of crude oil. In: BIOTECHNOLOGIES FOR IMPROVED PRODUCTION OF OIL \& GAS IN THE GULF OF GUINEA -BIPOG3, INTERNATIONAL CONFERENCE, WORKSHOP AND EXHIBITION, 1., 1-3 apr. 2009, Abuja. Proceedings... Abuja: BIPOG3, 2009c. p. 1-6.

CHIKERE, B. O.; CHIJIOKE-OSUJI, C. Microbial diversity and physicochemical properties of a crude oil polluted soil. Nigerian Journal of Microbiology, v. 20, p. 1039-1046, 2006.

EBUEHI, O. A. T.; ABIBO, I. B.; SHEKWOLO, P. D.; IHEAGWAM, K. S.; ADOKI, A.; OKORO, I. C. Remediation of crude oil contaminated soil by enhanced natural attenuation technique. Journal of Applied Science and Environmental Management, v. 9, p. 103-105, 2005.

EVANS, F. F.; ROSADO, A. S.; SEBASTIAN, G. V.; CASELLA, R.; MACHADO, P. L. O. A.; HOLMSTROM, C. et al. Impact of oil contamination and biostimulation on the diversity of indigenous bacterial communities in soil microcosms. FEMS Microbiology Ecology, v. 49, p. 295-305, 2004. http://dx.doi.org/10.1016/j.femsec.2004.04.007 
CHIKERE, C. B; SURRIDGE, K. J; CLOETE, T. E; OKPOKWASILI, G. C. Phylogenetic diversity of dominant bacterial communities during bioremediation of crude oil-polluted soil. Ambi-Agua, Taubaté, v. 6, n. 2, p. 61-76, 2011. (doi:10.4136/ambi-agua.186)

HAMAMURA, N.; OLSON, S. H.; WARD, D. M.; INSKEEP, W. P. Microbial population dynamics associated with crude oil biodegradation in diverse soils. Applied and Environmental Microbiology, v. 72, p. 6316-6324, 2006. http://dx.doi.org/10.1128/AEM.01015-06

HEINZEL, E.; HEDRICH, S.; JANNECK, E.; GLOMBITZA, F.; SEIFERT, J.; SCHLOMANN, M. Bacterial diversity in a mine water treatment plant. Applied and Environmental Microbiology, v. 75, p. 858-861, 2009. http://dx.doi.org/10.1128/AEM.01045-08

HEISS-BLANQUET, S.; BENOIT, Y.; MARECHAUX, C.; MONOT, F. Assessing the role of alkane hydroxylase genotypes in environmental samples by competitive PCR. Journal of Applied Microbiology, v. 104, p. 251-259, 2005.

IJAH, U. J. J.; ANTAI, S. P. Removal of Nigerian light crude oil in soil over a 12-month period. International Biodeterioration and Biodegradation, v. 51, p. 93 - 99, 2003a. http://dx.doi.org/10.1016/S0964-8305(01)00131-7

IJAH, U. J. J.; ANTAI, S. P. The potential use of chicken-drop microorganisms for oil spill remediation. The Environmentalist, v. 23, p. 89-95, 2003b. http://dx.doi.org/10.1023/A:1022947727324

JIMÉNEZ, N.; VIÑAS, M.; BAYONA, J. M.; ALBAIGES, J.; SOLANAS, A. M. The Prestige oil spill: bacterial community dynamics during a field biostimulation assay. Applied Microbiology and Biotechnology, v. 77, p. 935-945, 2007. http://dx.doi.org/10.1007/s00253-007-1229-9

KAPLAN, C. W.; KITTS C. L. Bacterial succession in a petroleum land treatment unit. Applied and Environmental Microbiology, v. 70, p. 1777-1786, 2004. http://dx.doi.org/10.1128/AEM.70.3.1777-1786.2004

KLOOS, K.; MUNCH, J. C.; SCHLOTER, M. A new method for the detection of alkane monooxygenase homologous genes (alkB) in soils based on PCR-hybridization. Journal of Microbiological Methods, v. 66, p. 486-496, 2006. http://dx.doi.org/10.1016/j.mimet.2006.01.014

KOREN, O.; KNEZEVIC, V.; RON, E. Z.; ROSENBERG, E. Petroleum pollution bioremediation using water-insoluble uric acid as the nitrogen source. Journal of Applied Microbiology, v. 69, p. 6337-6339, 2003. http://dx.doi.org/10.1128/AEM.69.10.6337-6339.2003

KUMAR, M.; KHANNA, S. Diversity of 16S rRNA and dioxygenase genes detected in coal tar-contaminated site undergoing active bioremediation. Journal of Applied Microbiology, v. 108, p. 1252-1262, 2010. http://dx.doi.org/10.1111/j.1365-2672.2009.04523.x

LAL, R.; PANDEY, G.; SHARMA, P.; KUMARI, K.; MALHOTRA, S.; PANDEY, R. et al. Biochemistry of microbial degradation of hexachlorohexane and prospects for bioremediation. Microbiology and Molecular Biology Reviews, v. 74, p. 58-80, 2010. http://dx.doi.org/10.1128/MMBR.00029-09

LEAHY, J. G.; COLWELL, R. R. Microbial degradation of hydrocarbons in the environment. Microbiology Reviews, v. 54, p. 305-315, 1990. 
CHIKERE, C. B; SURRIDGE, K. J; CLOETE, T. E; OKPOKWASILI, G. C. Phylogenetic diversity of dominant bacterial communities during bioremediation of crude oil-polluted soil. Ambi-Agua, Taubaté, v. 6, n. 2, p. 61-76, 2011. (doi:10.4136/ambi-agua.186)

MACNAUGHTON, S. J.; STEPHEN, J. R.; VENOSA, A. O.; DAVIS, G. A.; CHANG, Y. J.; WHITE, D. C. Microbial population changes during bioremediation of an experimental oil spill. Applied and Environmental Microbiology, v. 65, p. 3566-3574, 1999.

MAILA, M. P.; RANDIMA, P.; SURRIDGE, K.; DRØNEN, K.; CLOETE, T. E. Evaluation of microbial diversity of different soil layers at a contaminated diesel site. International Biodeterioration and Biodegradation, v. 55, p. 39-44, 2005. http://dx.doi.org/10.1016/j.ibiod.2004.06.012

MALIK, S.; BEER, M.; MEGHARAJ, M.; NAIDU, R. The use of molecular tools to characterize the microbial communities in contaminated soil and water. Environment International, v. 38, p. 265-276, 2008. http://dx.doi.org/10.1016/j.envint.2007.09.001

MARGESIN, R.; LABBE, D.; SCHINNER, F.; GREER, C. W.; WHYTE, L. G. Characterization of hydrocarbon degrading microbial populations in contaminated and pristine Alpine soils. Applied and Environmental Microbiology, v. 69, p. 3085-3092, 2003. http://dx.doi.org/10.1128/AEM.69.6.3085-3092.2003

MARGESIN, R.; HAMMERLE, M.; TSCHERKO, D. Microbial activity and community composition during bioremediation of diesel-oil contaminated soil: effects of hydrocarbon concentration, fertilizers and incubation time. Microbial Ecology, v. 55, p. 259-269, 2007.

MUYZER, G.; DE WAAL, D. C.; UITTERLINDEN, V. Profiling of complex microbial populations by denaturing gradient gel electrophoresis analysis of polymerase chain reaction-amplified genes coding for 16S rRNA. Applied and Environmental Microbiology, v. 59, p. 695-700, 1993.

NORLAND, S. Gel2K gel analysis software. Norway: University of Bergen, 2004. Available in: <http://www.im.uib.no/ nimsn/program/>. Access in: 2004.

NWEKE, C. O.; OKPOKWASILI, G. C. Effects of bioremediation treatments on the bacterial populations of soil at different depths. Nigerian Journal of Microbiology, v. 18, p. 363-372, 2004.

ODOKUMA, L. O.; IBOR, M. N. Nitrogen fixing bacteria enhanced bioremediation of a crude oil polluted soil. Global Journal of Pure and Applied Science, v. 86, p. 455468, 2002.

ODOKUMA, L. O.; DICKSON, A. A. Bioremediation of a crude oil-polluted tropical rain forest soil. Global Journal of Environmental Science, v. 2, p. 29-40, 2003.

OKPOKWASILI, G. C.; SOMERVILLE, C. C.; SULLIVAN, M.; GRIMES, D. J.; COLWELL, R. R. Plasmid mediated degradation of hydrocarbons in estuarine bacteria. Oil Chemistry and Pollution, v. 5, p. 117-129, 1986.

http://dx.doi.org/10.1016/S0269-8579(86)80003-X

OKPOKWASILI, G. C.; ODOKUMA, L. O. Tolerance of Nitrobacter to toxicity of some Nigerian crude oils. Bulletin of Environmental Contamination and Toxicology, v. 52, p. 388-395, 1994. http://dx.doi.org/10.1007/BF00197826

OKPOKWASILI, G. C. Microbes and the environmental challenge. Port Harcourt: University of Port Harcourt, 2006. p. 1-77. (Inaugural Lecture, n. 53)

OLLIVIER, B.; MAGOT, B. Petroleum microbiology. Washington, DC: American Society for Microbiology (ASM) Press, 2005. 
CHIKERE, C. B; SURRIDGE, K. J; CLOETE, T. E; OKPOKWASILI, G. C. Phylogenetic diversity of dominant bacterial communities during bioremediation of crude oil-polluted soil. Ambi-Agua, Taubaté, v. 6, n. 2, p. 61-76, 2011. (doi:10.4136/ambi-agua.186)

PHILP, J. C.; WHITELY, A. S.; CIRIC, L.; BAILEY, M. J. Monitoring bioremediation. In: ATLAS, R. M.; PHILP, J. Bioremediation: applied microbial solutions for Real-World Environmental Cleanup. Washington, DC: American Society for Microbiology (ASM) Press, 2005. p. 237-292.

POPP, N.; SCHLOMANN, M.; MAU, M. Bacterial diversity in the active stage of a bioremediation system for mineral oil hydrocarbon-contaminated soils. Microbiology, v. 152, p. 3291-3304, 2006. http://dx.doi.org/10.1099/mic.0.29054-0

QUATRINI, P.; SCAGLIONE, G.; DE PASQUALE, C.; REILA, S.; PUGLIA, A. M. Isolation of Gram-positive n-alkane degraders from a hydrocarbon contaminated Mediterranean shoreline. Journal of Applied Microbiology, v. 104, p. 251-259, 2008.

RAHMAN, K. S. M.; RAHMAN, T.; LAKSHMANAPERUMALSAMY, P.; BANAT, I. M. Occurrence of crude oil degrading bacteria in gasoline and diesel station soils. Journal of Basic Microbiology, v. 42, p. 284-291, 2002.

http://dx.doi.org/10.1002/1521-4028(200208)42:4<284::AID-JOBM284>3.0.CO;2-M

RODRIGUES, D. F.; SAKATA, S. K.; COMASSETO, J. V.; BICEGO, M. C.; PELLIZARI, V. H. Diversity of hydrocarbon-degrading Klebsiella strains isolated from hydrocarboncontaminated estuaries. Journal Applied of Microbiology, v. 106, p. 1304-1314, 2009. http://dx.doi.org/10.1111/j.1365-2672.2008.04097.x.

ROJAS-AVELIZAPA, N. G.; ROLDAN-CARRILLO, T.; ZEGARRA-MARTINEZ, H.; MUNOZ-COLUNGA, A. M.; FERNANDEZ-LINARES, L. C. A field trial for an exsitu bioremediation of a drilling mud-polluted site. Chemosphere, v. 66, p. 1595-1600, 2007. http://dx.doi.org/10.1016/j.chemosphere.2006.08.011

ROLING, W. F. M.; MILNER, M. G.; JONE, D. M.; LEE, K.; DANIEL, F.; SWANNELL, R. P. J. et al. Robust hydrocarbon degradation and dynamics of bacterial communities during nutrient-enhanced oil spill bioremediation. Applied and Environmental Microbiology, v. 68, p. 5537-5548, 2002. http://dx.doi.org/10.1128/AEM.68.11.55375548.2002

ROLING, W. F. M.; MILNER, M. G.; JONES, D. M.; FRATEPIETRO, F.; SWANNELL, R. P. J.; DANIEL, F.; HEAD I. M. Bacterial community dynamics and hydrocarbon degradation during a field scale evaluation of bioremediation in a mudflat beach contaminated with buried oil. Applied and Environmental Microbiology, v. 70, p. 2603-2613, 2004. http://dx.doi.org/10.1128/AEM.70.5.2603-2613.2004

ROSENBERG, E.; LEGMAN, R.; KUSHMARO, A.; TAUBE, R.; ADLER, E.; RON, E. Z. Petroleum bioremediation: a multi phase problem. Biodegradation, v. 3, p. 337-350, 1992. http://dx.doi.org/10.1007/BF00129092

ROSENBERG, E.; RON, E. Z. Bioremediation of petroleum contamination In: CRAWFORD, R. L.; CRAWFORD, D. L. Bioremediation: principles and application. Cambridge: Cambridge University Press, 1996. p. 100-124.

ROSENBERG, E.; LEGMAN, R.; KUSHMARO, A.; ADLER, E.; ABIR, H.; RON, E. Z. Oil bioremediation using insoluble nitrogen source. Journal of Biotechnology, v. 51, p. 273-278, 1996. http://dx.doi.org/10.1016/S0168-1656(96)01606-9 
CHIKERE, C. B; SURRIDGE, K. J; CLOETE, T. E; OKPOKWASILI, G. C. Phylogenetic diversity of dominant bacterial communities during bioremediation of crude oil-polluted soil. Ambi-Agua, Taubaté, v. 6, n. 2, p. 61-76, 2011. (doi:10.4136/ambi-agua.186)

RUBERTO, L.; DIAS, R.; BALBO, A. L.; VAZQUEZ, S. C.; HERNANDEZ, E. A.; CORMACK, W. P. M. Influence of nutrients addition and bioaugmentation on the hydrocarbon biodegradation of a chronically contaminated Antarctic soil. Journal of Applied Microbiology, v. 106, p. 1101-1110, 2006. http://dx.doi.org/10.1111/j.1365-2672.2008.04073.x

SEI, K.; SUGIMOTO, Y.; MORI, K.; MAKI, H.; KOHNO, T. Monitoring of alkane degrading bacteria in a sea water microcosm during crude oil degradation by polymerase chain reaction-based on alkane-catabolic genes. Environmental Microbiology, v. 5, p. 517-522, 2003.

http://dx.doi.org/10.1046/j.1462-2920.2003.00447.x

SICILIANO, S. D.; GERMIDA, J. J.; BANKS, K.; GREER, C. W. Changes in microbial community composition and function during a polyaromatic hydrocarbon phytoremediation field trial. Applied and Environmental Microbiology, v. 69, p. 483-489, 2003. http://dx.doi.org/10.1128/AEM.69.1.483-489.2003

SMALLA, K.; OROS-SICHLER, M.; MILLING, A.; HEUER, H.; BAUMGARTE, S.; BECKER, R. et al. Bacterial diversity of soils assessed by DGGE, T-RFLP and SSCP fingerprints of PCR-amplified 16S rRNA gene fragments: do the different methods provide similar results? Journal of Microbiological Methods, v. 69, p. 470-479, 2007. http://dx.doi.org/10.1016/j.mimet.2007.02.014

STROUD, J. L.; PATON, G. I.; SEMPLE, K. T. Microbe-aliphatic hydrocarbon interactions in soil; implications for biodegradation and bioremediation. Journal of Applied Microbiology, v. 102, p. 1239-1253, 2007.

http://dx.doi.org/10.1111/j.1365-2672.2007.03401.x

SURRIDGE, A. J. K.; DRØNEN, A. K.; WEHNER, F. C.; CLOETE, T. E. Phylogenetic and distance analyses of microbial populations from contaminated soils in South Africa based on denaturing gradient gel electrophoresis (DGGE) profiles. International Journal of Phytoremediation, v. 7, p. 1-12, 2005.

THERON, J.; CLOETE, T. E. Microbiological detection techniques In: CLOETE, T. E.; ATLAS, R. M. Basic and applied microbiology. Pretoria: Van Schaik Publishers, 2006. p .185-208.

VAN BEILEN, J. B.; FUNHOFF, E. G. Expanding the alkane oxygenase toolbox: new enzymes and applications. Current Opinion in Biotechnology, v. 16, p. 308-314, 2005. http://dx.doi.org/10.1016/j.copbio.2005.04.005

VAN BEILEN, J. B.; FUNHOFF, E. G. Alkane hydroxylases involved in microbial alkane degradation. Applied Microbiology Biotechnology, v. 74, p. 13-21, 2007.

http://dx.doi.org/10.1007/s00253-006-0748-0

VAN ELSAS, J. D.; JANSSON, J. K.; TREVORS, J. K. Modern soil microbiology. 2. ed. New York: CRC Press, 2007. p. 387-429.

VAN HAMME, J. D.; SINGH, A.; WARD, O. P. Recent advances in petroleum microbiology. Microbiology and molecular biology reviews, v. 67, p. 503-549, 2003. http://dx.doi.org/10.1128/MMBR.67.4.503-549.2003

WILLIAMS, C. M.; GRIMES, J. L.; MIKKELSEN, R. L. The use of poultry litter as cosubstrate and source of inorganic nutrients and microorganisms for the ex-situ biodegradation of petroleum compounds. Poultry Science, v. 78. p. 956-964, 1999. 
CHIKERE, C. B; SURRIDGE, K. J; CLOETE, T. E; OKPOKWASILI, G. C. Phylogenetic diversity of dominant bacterial communities during bioremediation of crude oil-polluted soil. Ambi-Agua, Taubaté, v. 6, n. 2, p. 61-76, 2011. (doi:10.4136/ambi-agua.186)

ZENGLER, K. Accessing uncultivated microorganisms: from the Environment to Organisms and Genomes and Back. Washington, DC: American Society for Microbiology Press, 2008. p. 153-186.

ZUCCHI, N.; ANGIOLINI, L.; BORIN, S.; BRUSETTI, L.; DIETRICH, N.; GIGLIOTTI, C. et al. Response of bacterial community during bioremediation of an oil polluted soil. Journal of Applied Microbiology, v. 94, p. 248 - 257, 2003.

http://dx.doi.org/10.1046/j.1365-2672.2003.01826.x 